\title{
PERENCANAAN BISNIS PENGERINGAN PALA DENGAN TEKNOLOGI OVEN DI KECAMATAN TAMANSARI KABUPATEN BOGOR
}

\author{
Monicha Septya Harni ${ }^{1}$, dan Siti Jahroh ${ }^{2)}$ \\ ${ }^{1,2)}$ Departemen Agribisnis, Fakultas Ekonomi dan Manajemen, Institut Pertanian Bogor \\ ${ }^{1)}$ monichaseptya@gmail.com
}

\begin{abstract}
Drying nutmeg companies rely on sunlight to dry the nutmeg. In fact, Bogor District has a high rainfall intensity. This condition can be overcome by using oven technology. By using oven technology, production process does not rely on the weather, the product will dry evenly, and does not require a large area. The purpose of this study is to analyze the business potential of nutmeg in Tamansari Sub-district and to design a business planbased on financial and non financial aspects. Interview was conducted to farmers and three nutmeg drying companies who were selected by snow ball sampling method. Other data were obtained from literature such as newspaper, internetand others. The results revealed that Tamansari Sub-district is an area that has the potential of natural resources, human resources, demand and marketing to develop business nutmeg. Price of dried seed was determined as Rp110 000 per $\mathrm{kg}$ and dried mace as Rp130 000 per $\mathrm{kg}$. The target market is the export market. CV is chosen as the business form. NPV is Rp827 682 000, Net B/C3.83, IRR 67 per cent and payback period 1.92(1 year 9 months). BEP value is Rp108 248600 in the first year and Rp372 745700 in the next years. Business planning is feasible based on financial and non-financial analyses.
\end{abstract}

Keyword(s): drying nutmeg, oven technology, investment criteria

\begin{abstract}
ABSTRAK
Perusahaan pengeringan pala hanya mengandalkan sinar matahari untuk mengeringkan pala. Padahal Kabupaten Bogor memiliki intensitas hujan yang tinggi. Kondisi ini dapat disiasati dengan menggunkan teknologi oven. Dengan teknologi oven, proses produksi tidak bergantung pada cuaca, hasil produksi kering merata serta tidak membutuhkan lahan yang besar. Oleh karena itu perencanaan bisnis pengeringan pala dengan teknologi oven ini penting untuk dilakukan. Tujuan dari penelitian ini ialah untuk menganalisis potensi usaha pala di Kecamatan Tamansari dan merancang rencana bisnis secara finansial dan non finansial. Pengumpulan data dilakukan dengan wawancara ke petani dan tiga perusahaan pengeringan pala yang dipilih dengan metode snow ball sampling. Data lainnya diperoleh dari berbagai literatur seperti media cetak, internet dan lain-lain. Berdasarkan hasil penelitian diketahui bahwa Kecamatan Tamansari merupakan daerah yang memiliki potensi sumberdaya alam, sumberdaya manusia, permintaan dan pemasaran untuk mengembangkan usaha pala. Harga biji pala kering ditetapkan Rp110 000 dan fuli kering Rp130 000 per kilogram. Target pasar yang akan dituju ialah pasar ekspor. Badan usaha yang direncanakan berbentuk CV. Nilai NPV adalah Rp827 682 000, Net B/C adalah 3.83, nilai IRR adalah 69 persen dan nilai payback period adalah 1.92 (1 tahun 9 bulan). Nilai BEP dapat tercapai saat memperoleh penerimaan sebesar Rp108 248600 pada tahun pertama dan Rp372 745700 pada tahun selanjutnya. Berdasarkan analisis finansial dan non finansial, perencanaan ini layak untuk dijalankan.
\end{abstract}

Kata Kunci: pengeringan pala, teknologi oven, kriteria investasi 


\section{PENDAHULUAN}

Indonesia merupakan produsen terbesar pala dunia yang dibuktikan dari pangsa pasarnya sebesar 75 persen $^{3}$. Pala juga memiliki nilai jual yang tinggi. Pala Indonesia sangat diminati oleh konsumen dunia disebabkan karakteristik uniknya. Keunggulan pala Indonesia di pasar dunia ialah memiliki aroma khas dan rendemen minyak tinggi yang tidak dimiliki pala dari negara lain (Lusianah et al. 2010). Besarnya pangsa pasar dan nilai jual pala Indonesia ini menjadi peluang usaha bagi masyarakat di daerah pengembangan perkebunan pala di Indonesia.

Provinsi Jawa Barat merupakan penghasil dan sentra produksi pala terbesar di Wilayah Jawa dan Kabupaten Bogor sebagai produsen utamanya (Dirjenbun 2014). Kecamatan Tamansari merupakan salah satu sentra produksi pala di Kabupaten Bogor.

BPS (2013) menyatakan bahwa Kecamatan Tamansari merupakan daerah penghasil pala peringkat ketiga dalam jumlah produksi dan kedua dalam luas lahan, namun produktivitasnya relatif rendah.

Selama ini usaha pengeringan pala dilakukan dengan teknik sederhana, yaitu mengandalkan sinar matahari untuk mengeringkan pala. Artinya proses produksi sangat bergantung pada cuaca. Sedangkan diketahui bahwa Kabupaten Bogor adalah daerah yang memiliki intensitas hujan yang tinggi.

Teknologi oven merupakan teknologi pengeringan yang dapat menyiasati kondisi cuaca yang tidak menentu tersebut. Dengan menggunakan oven, proses produksi tidak bergantung pada cuaca, hasil produksi kering merata serta tidak membutuhkan lahan yang besar. Namun, hingga saat ini perusahaan pengeringan di Kecamatan Tamansari belum menggunakannya.

Berdasarkan informasi yang telah dipaparkan sebelumnya, penelitian mengenai perencanaan bisnis pengeringan pala dengan teknologi oven ini penting untuk dilakukan agar diketahui kelayakannya. Adapun rumusan masalahnya ialah :

1. Bagaimana potensi usaha pala di Kecamatan Tamansari?

2. Bagaimana rencana bisnis yang harus dirumuskan agar bisnis pengeringan pala dengan teknologi oven layak secara finansial dan non finansial?

3. Apakah perencanaan bisnis pengeringan pala dengan teknologi oven layak untuk dijalankan?

Berdasarkan perumusan masalah yang telah dipaparkan, maka tujuan dari penelitian ini adalah menganalisis potensi usaha pala di Kecamatan Tamansari, merancang rencana bisnis dan membuktikan kelayakan usaha pengeringan pala dengan teknologi oven di Kecamatan Tamansari

\section{KERANGKA PEMIKIRAN}

Rencana bisnis adalah suatu dokumen tertulis yang menggambarkan secara sistematis suatu bisnis yang diusulkan. Karakteristik perencanaan bisnis yaitu

\footnotetext{
${ }^{3}$ Sytarno. 2013. Biji Pala Indonesia Dihadang Uji Mutu Internasional [terubung berkala]. [diakses pada 2016 Mar 3]. Terdapat pada : http://industri.bisnis.com/read/20130630/99/147783/biji-pala-indonesia-dihadang-uji-mutuinternasional
} 
harus memuat alasan-alasan atau asumsi sebagai dasar perhitungan.

Produk yang akan diproduksi berupa biji dan fuli pala kering berkualitas diproses dengan menggunakan teknologi pengering dan bahan baku pilihan. Produk diproses dengan penangan pascapanen yang baik sesuai dengan standar mutu SNI 01-0006-1993 dan SNI 01-0007-1993.

Manajemen pemasaran ialah proses perencanaan dan pelaksanaan dari perwujudan pemberian harga, promosi, dan distribusi dari barang-barang, jasa dan gagasan untuk menciptakan pertukaran dengan kelompok sasaran yang memenuhi tujuan pelanggan dan atau organisasi (Asmarantaka 2012). Agar pemasar dapat lebih mudah dan efisien maka dapat menggunakan pemasaran STP (Segmenting, Targeting, Positioning) (Kolter, Susanto 2000). Setelah itu menentukan bauran pemasaran 4P (marketing mix) yaitu product, place, promotion, price berdasarkan pelanggan yang dibidik dan posisi yang diinginkan.

Manajemen operasi merupakan pengarahan dan pengendalian suatu proses secara sistematis untuk mengubah sumberdaya menjadi barang dan jasa oleh manajer operasi.

Pengorganisasian berarti mengelompokkan organisasi-organisasi ke dalam jenis pekerjaan tertentu (berdasarkan pekerjaan) dan hubungan kerja sebaikbaiknya. Jenis pekerjaan harus disusun berdasarkan kebutuhan dan efisiensi (Nurmalina 2014). Level manajemen terdiri atas stop, middle, dan line management. Adapun aspek manajemen organisasi dan SDM meliputi aspek legal dan ruang lingkup/batasan pengembangan usaha, perizinan, struktur organisasi, upah dan gaji.

\section{Rencana Keuangan}

Laporan keuangan adalah informasi penting dan cara yang digunakan dalam menggambarkan posisi keuangan perusahaan (Keown et al 2001 dalam Rachmina, Feryanto 2014). Tujuan laporan keuangan ialah untuk memberikan informasi terkait dengan sumbar ekonomi dan kewajiban serta modal suatu perusahaan dan mengestimasi potensi perusahaan dalam menghasilkan laba. Laporan keuangan yang pada umumnya digunakan oleh banyak organisasi adalah laporan arus kas dan laba rugi.

Ada beberapa hal yang perlu dianalisis lebih lanjut untuk menyusun suatu perencanaan bisnis yaitu Net Present Value (NPV), Internal Rate Return (IRR), Benefit Cost Ratio (Net B/C), Payback Period (PP), Break even poin (BEP) (Nurmalina et al. 2009).

\section{METODE PENELITIAN}

\section{Lokasi dan Waktu Penelitian}

Penelitian dilakukan di tiga perusahaan pengeringan pala Kecamatan Tamansari Kabupaten Bogor yaitu UD. Putra Mandiri, Perusahaan Bapak Jaya dan Perusahaan Bapak Ozi. Pemilihan lokasi dilakukan secara sengaja (purposive) dengan pertimbangan Kecamatan Tamansari merupakan sentra produksi dan tiga perusahaan tersebut merupakan perusahaan yang cukup mendominasi di Kecamatan Tamansari. Penelitian di- 
laksanakan pada Bulan Februari hingga Maret 2015 untuk pengambilan data

\section{Metode Pengambilan Sampel}

Teknik pengumpulan data primer dilakukan dengan menggunakan metode Snow Ball Sampling.

\section{Metode Pengolahan dan Analisis Data}

Pengolahan data dilakukan dengan dua analisis yaitu analisis non finansial dan analisis finansial. Analisis non finansial terdiri dari rencana produk, strategi pemasaran, operasional, manajemen organisasi, dan risiko. Adapun analisis finansial merupakan perencanaan keuangan dengan menggunakan kriteria investasi seperti NPV, IRR, Net B/C rasio, Payback Period, dan BEP melalui laporan cashflow dan laba rugi.

\section{Net Present Value (NPV)}

Net Present Value (NPV) merupakan selisih antara total present value penerimaan (benefit) dengan total present value pengeluaran (cost). Suatu bisnis dikatakan layak atau dapat memberi keuntungan apabila nilai NPV lebih dari $0(\mathrm{NPV}>0)$.

$$
\mathrm{NPV}=\sum_{t=1}^{10} \frac{B t-C t}{(1+i) t}
$$

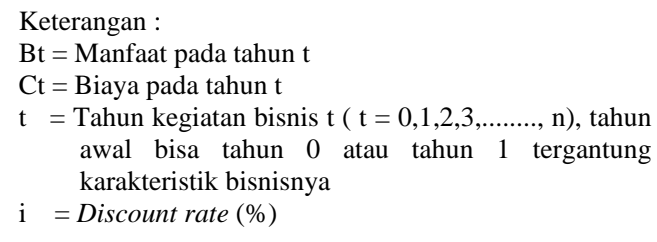

\section{Internal Rate of Return (IRR)}

Internal Rate of Return menunjukkan seberapa besar pengembalian bisnis terhadap investasi yang ditanamkan. Sebuah bisnis dikatakan layak apabila nilai IRR lebih besar dari discount rate.

$$
\mathrm{IRR}=i_{1}+\frac{N P V_{1}}{N P V_{1}-N P V_{2}} x\left(i_{2}-i_{1}\right)
$$

$$
\begin{aligned}
& \multicolumn{2}{l}{\text { Keterangan : }} \\
& \mathrm{i} 1= \text { Nilai percobaan pertama untuk discount rate } \\
& \text { positif } \\
& \mathrm{i} 2 \quad= \text { Nilai percobaan kedua untuk discount rate } \\
& \text { negatif } \\
& \mathrm{NPV} 1= \text { Nilai percobaan pertama untuk NPV } \\
& \mathrm{NPV} 2= \text { Nilai percobaan kedua untuk NPV }
\end{aligned}
$$

\section{Net Benefit- Cost Ratio (Net B/C)}

Net B/C adalah rasio antara manfaat bersih bernilai positif dengan manfaat bersih bernilai negatif. Suatu bisnis dikatakan layak apabila nilai Net B/C Rasio lebih besar dari 1 (Net B/C Rasio>1).

$$
\text { Net } B / C=\frac{\sum_{t=1}^{10} \frac{B t-C t}{(1+i)^{t}}}{\left|\sum_{t=1}^{10} \frac{B t-C t}{(1+i)^{t}}\right|} \frac{(B t-C)>0}{(B t-C)<0}
$$

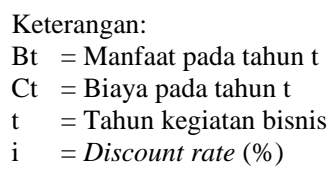

\section{Payback Period (PP)}

Payback Period mengukur seberapa cepat investasi bisa kembali. Semakin cepat tingkat pengembalian modal, maka para investor akan semakin tertarik untuk berinvestasi pada bisnis tersebut.

$$
\mathrm{PP}=\frac{I}{A b}
$$

\footnotetext{
Keterangan :

I = Biaya investasi yang diperlukan

$\mathrm{Ab}=$ manfaat bersih yang dapat diperoleh pada setiap tahunnya
} 


\section{Break Even Point (BEP)}

Break Even Point (BEP) merupakan suatu keadaan pada kondisi titik impas sehingga pada kondisi ini perusahaan tidak mengalami kerugian maupun keuntungan $(\mathrm{P}=\mathrm{ATC}$ minimum). Berikut cara mencari BEP rupiah dua joint products.

$$
\begin{gathered}
\text { BEP Rupiah }=\frac{\text { Biaya Tetap }}{\text { Bobot kontribusi }} \\
\text { atau } \\
\frac{F C}{(1-V C / P) W i}
\end{gathered}
$$

Keterangan :

$\mathrm{FC}=$ Biaya tetap

$\mathrm{VC}=$ Biaya variabel per unit

$\mathrm{P}=$ Harga per unit

$\mathrm{Wi}=$ Persentase hasil penjualan

\section{HASIL DAN PEMBAHASAN}

\section{Gambaran Umum Lokasi Usaha}

Berdasarkan data monografi, Kecamatan Tamansari berada pada ketinggian $700 \mathrm{mdpl}$, suhu $25^{\circ} \mathrm{C}$ hingga $30^{\circ} \mathrm{C}$, curah hujan rata-rata per tahunnya sebesar 3000 $\mathrm{mm} /$ tahun dan struktur tanah berpasir. Kondisi ini dinilai amat sesuai dengan karakteristik kondisi optimum budidaya pala.

Jumlah penduduk Kecamatan Tamansari mencapai 86868 jiwa dengan kondisi kualitas SDM tergolong rendah karena sebagian besar masyarakatnya berpendidikan rendah (tidak tamat SD). Sebagian masyarakat berprofesi sebagai petani (petani pemilik tanah 7004 orang, petani penggarap tanah 4 022, buruh tani 6841 orang).

\section{Potensi Usaha Pala}

Kecamatan Tamansari memiliki karakteristik topografi dan iklim wilayah yang sesuai dengan kondisi dan syarat tumbuh pala. Karakteristik topografi dan iklim yang sesuai ini menjadikan Kecamatan Tamansari berpotensi untuk dikembangkan budidaya pala.

Kecamatan Tamansari memiliki jumlah rumah tangga usaha pala terbesar dibandingkan dengan kecamatan lainnya yaitu berjumlah 1652 rumah tangga hingga sebagian besar masyarakat

Indonesia menjadi produsen terbesar pala dunia. Pangsa pasarnya mencapai 90 persen. Permintaan pala ini menjadi potensi keuntungan yang besar jika memasuki pasarnya.

Adapun tantangan bisnis pala ini ialah perbaikan kualitas yang sesuai dengan standar ekspor. Saat ini kualitas pala Indonesia masih tergolong rendah sehingga terjadi beberapa kali Eropa menolak ekspor pala Indonesia. Rendahnya kualitas pala disebabkan oleh pengolahan pascapanen yang kurang tepat. Oleh karena itu, dapat menyediakan pala berkualitas adalah peluang dan tantangan yang prospektif untuk dijalankan.

\section{RENCANA BISNIS}

Asumsi dasar yang digunakan dalam perencanaan pengeringan pala ini ialah: Bahan baku berupa biji pala basah berfuli yang diperoleh dari petani pala di Kecamatan Tamansari. Lokasi produksi terletak di Desa Tamansari, karena dekat dengan sumber bahan baku.

Pada perencanaan operasional, hari kerja ditetapkan selama 20 hari per bulan yang berlangsung selama 12 bulan setiap 
tahun. Pada tahun pertama diasumsikan hanya berproduksi 4 bulan sedangkan 8 bulan sebelumnya digunakan untuk perisapan dan pendirian perusahaan. Dalam sebulan direncanakan menghasilkan 1220 kg biji kering dan 146.4 kg fuli kering.

Pengeringan fuli menggunakan mesin 0VG-P20 selama 6 jam sedangkan pengeringan biji dilakukan selama 9 jam (3 jam pengeringan I dan 6 jam pengeringan 2). Waktu kerja dimulai dari pukul 7.00 hingga pukul 17.00 WIB dengan waktu jeda istirahat pada pukul 12.00 hingga pukul 13.00 WIB.

Pendistribusian produk dilakukan 1 kali dalam sebulan yaitu pekan kedua dan keempat melalui mekanisme Free On Board. Modal investasi dan produksi diperoleh dari pinjaman investor dengan sistem bagi hasil 30 persen selama jangka waktu 5 tahun.

\section{Strategi dan Rencana Pemasaran}

Segmentasi pasar dibagi berdasarkan penggunaan dan geografis. Berdasarkan penggunaan, segmentasi pasar produk ialah perusahaan minyak atsiri dan perusahaan rempah-rempah. Berdasarkan geografis, segmentasi dapat dikelompokkan menjadi dalam dan luar negeri. Target pasar yang dipilih untuk usaha pengeringan biji dan fuli pala ini ialah pasar ekspor dengan negara tujuan Uni Eropa, Vietnam, dan Amerika. Hal ini didasari oleh data empiris yang menunjukkan bahwa Negara tersebut sebagai importir pala terbesar.

Produk yang dihasilkan ialah fuli dan biji pala kering yang diproses menggunakan teknologi pengeringan yang mengacu pada panduan pascapanen pada Peraturan Menteri Pertanian Nomor 53/Permentan/OT.140/9 /2012 tentang Pedoman Penanganan Pascapanen Pala (Kementan 2012).

Harga jual yang ditetapkan untuk biji kering ialah Rp110 000 dan fuli kering sebesar Rp130 000. Penetapan harga berdasarkan harga pasar internasional. Promosi produk dilakukan melalui pameran, website, brosur, kunjungan dan lain-lain.

Pengumpul yang dianggap leader biasanya membeli pala dari petani sebanyak $400 \mathrm{~kg}$ per hari. Petani tidak terikat dalam menjual pala. Preferensi petani dalam menjual pala tergantung pada kemudahan transaksi dan harga yang ditawarkan oleh pengumpul.

\section{Rencana Operasional}

Bahan baku diperoleh dari petani Kecamatan Tamansari. Pala yang digunakan adalah pala tua berusia 6 sampai 7 bulan setelah berbunga karena pada usia ini rendemen minyak fuli mampu mencapai rata-rata rendemen tertinggi yaitu 13.75 persen (Sutarno, 1995 dalam Mulyono, 1997).

Teknologi yang digunakan adalah teknologi mesin pengering tipe OVEN40MS dan OVG-P20 dan pemecah tempurung pala. Alat yang digunakan terbuat dari bahan stainless stell tidak merusak kualitas produk. Penggunaan mesin bertujuan agar hasil pengeringan merata dan seragam, mudah dikontrol, lebih ringkas dalam waktu pengeringan, dan tidak tergantung pada cuaca yang sering kali berubah-ubah. 
Proses produksi dilakukan sebagai berikut :

a. Pemisahan daging, fuli dan biji

b. Pengeringan fuli

Pengeringan fuli menggunakan mesin pengering OVC-20 dengan suhu $45^{\circ} \mathrm{C}$ selama 6 jam hingga kadar airnya 10-12 persen. Setelah itu dapat dilakukan pengemasan dan penyimpanan.

c. Pengeringan Biji

Pengeringan awal pada biji pala yang masih bertempurung pada suhu $45^{\circ} \mathrm{C}$ hingga kadar air sekitar 8 hingga 10 persen dengan munggunakan mesin OVEN-40 MS selama 9 jam. Kemudian tempurung pala dikupas dan disortasi untuk memisahkan antara produk yang akan dijadikan bumbu dapur dan minyak. Setelah dikupas biji yang digunakan sebagai bumbu dapur direndam dengan air kapur agar mencegah tumbuhnya cendawan kemudian dikeringkan kembali hingga kadar air 10 hingga 12 persen. Pengeringan akhir biji pala dilakukan selama 3 jam. Setelah itu biji siap untuk dikemas dengan plastik.

d. Pengelolaan Limbah

Limbah yang berupa bahan organik akan dijadikan pupuk sedangkan limbah cairan dialirkan ke saluran dan pembuangannya dilakukan secara baik sehingga tidak menimbulkan genangan yang dapat menjadi sumber penyakit.

Lokasi yang dipilih untuk usaha pengeringan biji dan fuli pala ini adalah Desa Tamansari karena jauh dari tempat pembuangan sampah atau tempat yang sudah tercemar, dan yang utama ialah dekat dengan sentra produksi sehingga menghemat biaya transportasi dan menjaga kualitas produk.

Produk harus mendapat perlakuan pascapanen yang baik dan benar berdasarkan pedoman pascapanen yang mengacu pada prinsip-prinsip Good Handling Practices (GHP) dan Good Agricultural Practices (GAP). Standar mutu biji pala menurut SNI nomor SNI 01-0006-1993 sedangkan kriteria untuk menentukan standar kualitas fuli yaitu berdasarkan SNI 01-0007-1993.

SOP pelaksanaan aktivitas produksi sebagai berikut :

1. Pemeriksaan dan penyortiran bahan baku sesuai dengan kriteria keseragaman yang ditentukan

2. Perendaman dengan air kapur pada biji konsumsi

3. Pengeringan dengan menggunakan mesin pengering pada suhu $57^{\circ} \mathrm{C}$ untuk fuli dan $45^{\circ} \mathrm{C}$ untuk biji selama 24 jamhingga menghasilkan kadar air 10 persen

4. Penyortiran berdasarkan bentuk dan ukuran

5. Produk yang telah dikemas kemudian disimpan dalam gudang sebelum didistribusikan maksimal selama tiga bulan setelah pengolahan.

6. Membersihkan peralatan setelah penggunaan

7. Setiap pekerja harus menjaga sanitasi alat dan proses produksi

8. Setiap pekerja harus menjaga kebersihan dan keamanan 


\section{Rencana Organisasi dan SDM}

Aspek legal organisasi yang dipilih untuk usaha pengeringan pala ini ialah persekutuan komanditer (CV). CV terdiri dari seorang pesero yang melibatkan dirinya secara penuh dan/atau secara tanggung menanggung (karena bertindak sebagai pengurus) dan pesero lainnya yang tidak turut mengurus perseroan oleh karena itu tidak turut menanggung kerugian perseroan kecuali sebatas uang yang dilepaskannya dalam perseroan.

Struktur organisasi terdiri dari seorang direktur, 2 orang manajer (produksi dan pemasaran) serta 4 orang karyawan produksi.

Deskripsi dan spesifikasi kerja adalah sebagai berikut :

1. Direktur bertugas mengelola pelaksanaan usaha

2. Manajer produksi melakukan fungsi manajerial produksi

3. Manajer pemasaran bertugas melakukan fungsi manajerial pemasaran

4. Karyawan sortasi dan pengeringan bertugas melakukan pemilahan dan pengeringan pala

5. Karyawan pengemasan bertugas melakukan pengemasan produk

Ketentuan gaji dan upah ditetapkan berdasarkan tugas dan tanggung jawab yang dibebankan dengan mengacu pada ketetapan Gubernur Jawa Barat No. 561/Kep.1636-bangsos/2014 upah minimum regional (UMR) Kabupaten Bogor untuk industri pengolahan ini adalah sebesar Rp2 578 576. Penyerahan upah dilakukan setiap sebulan sekali pada pekan pertama di awal bulan.

\section{Rencana Kemitraan}

Kemitraan dilakukan untuk mempermudah dan mempercepat tercapainya tujuan perusahaan melalu pihak-pihak yang terlibat dalam bisnis pala. Kemitraan dapat dilakukan kepada pembeli, dan agen. Adanya kemitraan terhadap agen bertujuan agar perusahaan mendapat kepastian pasokan bahan baku Sedangkan tujuan kerjasama kepada pembeli yang paling penting ialah kepastian pasar.

\section{Analisis Manajemen Risiko}

Adapun risiko yang mungkin terjadi pada usaha pengeringan biji dan fuli pala serta upaya mengatasinya terdapat pada Lampiran 1.

\section{Rencana Keuangan}

Biaya investasi yang dikeluarkan pada awal usaha sebesar Rp324 352000. Setiap komponen investasi akan mengalami penyusutan dari tahun ke tahun. Total nilai penyusutan dari barang-barang dalam usaha pengeringan dan pengemasan ini sebesar Rp23 507900 per tahun. Adapun rincian biaya investasi awal dan penyusutan terdapat pada Lampiran 2 dan 3.

Besarnya biaya total biaya operasional dalam satu tahun ialah Rp1 405 368000 yang terdiri atas Rp258 134400 untuk biaya tetap dan Rp1 147233600 untuk biaya variabel. Adapun rincian biaya operasional yang digunakan terdapat pada Lampiran 4 dan 5.

Usaha pengeringan pala ini memberikan manfaat berupa penerimaan hasil penjualan sebesar Rp76 128000 pada tahun pertama dan Rp228 384000 di tahun selanjutnya. 
Nilai BEP untuk biji dan fuli kering dapat tercapai saat memperoleh penerimaan sebesar Rp108 248600 pada tahun pertama dan Rp372 745700 pada tahun selanjutnya. Adapun rincian BEPnya dapat dilihat pada Lampiran 6.

Bisnis ini dapat dikatakan layak untuk dijalankan karena nilai NPV sebesar Rp827 682000 (NPV>0), artinya bisnis pengeringan biji dan fuli pala ini menguntungkan, Net $\mathrm{B} / \mathrm{C}$ rasio senilai 3.83 artinya terdapat keuntungan dari manfaat bersih yang dihasilkan terhadap satu satuan kerugian dari bisnis tersebut, nilai IRR adalah 69 persen (IRR $>$ DF) artinya NPV 0 terjadi padatingkat discount rate 69 persen dan nilai payback period menggambarkan kecepatan pengembalian biaya investasi. Nilai payback period adalah 1.92 (1 tahun 9 bulan) artinya pengembalian biaya investasi dapat dikatakan cepat $(\mathrm{PP}<10$ tahun). Rincian laporan arus kas dapat dilihat pada Lampiran 7.

Berdasarkan laporan laba rugi usaha ini diperkirakan memperoleh keuntungan bersih setelah pajak sebesar Rp50 224 000 pada tahun pertama dan Rp111 442 000 pada tahun berikutnya. Laba yang diperoleh akan dibagikan kepada direktur selaku pemilik dan pengelola dan investor selaku penyedia modal masing-masing sebesar 30 persen. Rincian laporan laba rugi dapat dilihat pada Lampiran 8.

Untuk memenuhi kebutuhan modal awal dalam berinvestasi, perusahaan membutuhkan pinjaman dari investor sebesar Rp564 580000 di tahun pertama. Jangka waktu pinjaman yang ditetapkan selama lima tahun. Perusahaan harus membayar cicilan pokok pinjaman sebesar Rp112 916000 ditambah nilai bagi hasil untuk investor.

\section{SIMPULAN DAN SARAN Simpulan}

Kecamatan Tamansari merupakan salah satu sentra produksi pala unggulan karena memiliki potensi untuk mengembangkan usaha pala diantaranya ialah melalui potensi sumberdaya alam, sumberdaya manusia, permintaan, pemasaran dan kondisi usaha saat ini. Potensipotensi tersebut ini tentu dapat dilihat sebagai peluang bisnis bagi masyarakat Kecamatan Tamansari.

Perencanaan bisnis pengeringan pala dengan teknologi oven diformulasikan untuk mengembangkan potensi usaha pala di Kecamatan Tamansari serta memperbaiki kualitas biji dan fuli kering yang dihasilkan. Adapun perencanaan yang dibuat ialah perencanaan strategi dan pemasaran, operasional, organisasi dan SDM, kemitraan, risiko dan keuangan. Dari perencanaan tersebut ditetapkan bahwa pada tahun pertama dihasilkan 4880 Kg biji kering dan 585.6 Kg fuli kering pada tahun pertama yang diproduksi selama 4 bulan. Pada tahun berikutnya dihasilkan $14640 \mathrm{Kg}$ biji kering dan $1765.8 \mathrm{Kg}$ fuli kering pada tahun berikutnya yang diproduksi selam 12 bulan. Harga biji kering per kilogram ialah Rp110 000 sedangkan harga fuli kering Rp130 000. Tujuan pasar produk ialah pasar ekspor di Uni Eropa, Vietnam dan Amerika Serikat. Produk diolah dengan menggunakan teknologi pengering. Perusahaan pengeringan biji dan fuli pala ini direncanakan berbentuk badan usaha persekutuan komanditer. 
Berdasarkan hasil perhitungan proyeksi kriteria investasi diketahui bahwa bisnis pengeringan pala dengan teknologi oven ini layak untuk dijalankan karena memenuhi kriteria kelayakan investasi yang diantaranya ialah NPV sebesar Rp827 682000 (NPV>0), Net B/C senilai 3.83, nilai IRR adalah 69 persen (IRR $>$ DF) dan nilai payback period adalah 1.92 (1 tahun 9 bulan). Nilai BEP dapat tercapai saat memperoleh penerimaan sebesar Rp108 248600 pada tahun pertama dan Rp372 745700 pada tahun selanjutnya.

\section{Saran}

Saran yang dapat diberikan setelah dilakukan penelitian rencana bisnis pengeringan pala dengan teknologi melalui pendekatan korporasi di Kecamatan Tamansari ialah untuk melengkapi perencanaan bisnis pengeringan biji dan fuli pala ini, dapat dilakukan penelitian lanjutan mengenai strategi bisnis pengolahan pala dengan teknologi oven.

\section{DAFTAR PUSTAKA}

[BPS] Badan Pusat Statistik (ID). 2013. Kabupaten Bogor dalam Angka 2013. Jakarta : BPS

[Kementan] Kementerian Pertanian (ID) 2012. Peraturan Menteri Pertanian Nomor

53/Permentan/Ot.140/9/2012

Tentang Pedoman Penanganan Pascapanen Pala. Jakarta (ID)

Asmarantaka RW. 2012. Pemasaran Agribisnis. Bogor (ID): Departemen Agribisnis IPB
Kolter, Susanto AB. 2000. Manajemen Pemasaran Indonesia. Jakarta(ID) : Salemba Empat

Lusianah, Syamsun M, Palupi NS. 2010. Strategi dan Prospek Pengembangan Industri Produk Olahan Minyak Pala Dalam Rangka Pemberdayaan Masyarakat di Kabupaten Bogor. Manajemen IKM 5(1) : 65-79

Mulyono E. 1997. Permasalahan, Penanganan, dan Pengolahan Pala. Jurnal Penelitian dan Pengembangan Pertanian.16(2): 65-70

Nurmalina R. 2014. Perencanaan Organisasi dan SDM [Slide MK Perencanaan Bisnis]. Bogor (ID): Departemen Agribisnis

Nurmalina R, Sarianti T, Karyadi A. 2010. Studi Kelayakan Bisnis. Bogor (ID): Departemen Agribisnis IPB

Rachmina D, Feryanto. 2014. Pembiayaan Agribisnis. Bogor (ID): Departemen Agribisnis IPB 


\section{Lampiran 1. Analisis Manajemen Risiko}

\begin{tabular}{|c|c|c|c|}
\hline No & Sumber Risiko & Peluang terjadinya & Upaya pencegahan/penanggulangan \\
\hline \multirow[t]{7}{*}{1} & Risiko Produksi & Inefisiensi produksi & $\begin{array}{l}\text { Menekan biaya produksi yang tidak efisien dan } \\
\text { meningkatkan produksi }\end{array}$ \\
\hline & & $\begin{array}{l}\text { Penurunan kualitas produk } \\
\text { dan kegagalan produksi }\end{array}$ & $\begin{array}{l}\text { Melakukan pencegahan sebelum timbulnya } \\
\text { risiko seperti pemberian kapur (fumigasi), } \\
\text { memperbaiki cara pemanenan, dan } \\
\text { menggunakan peralatan yang tidak merusak } \\
\text { kualitas produk sesuai demam standar } \\
\text { pengolahan pala }\end{array}$ \\
\hline & & Fluktuasi bahan baku & Penjadwalan dalam pemanenan \\
\hline & & Kerusakan alat dan mesin & Melakukan upaya pemeliharaan mesin \\
\hline & & Inefisiensi SDM & $\begin{array}{l}\text { Menambah/mengurangi } \\
\text { perhitungan kebutuhan }\end{array}$ \\
\hline & & Pencurian & $\begin{array}{l}\text { Melakukan piket jaga dan memasang sarana } \\
\text { keamanan seperti CCTV }\end{array}$ \\
\hline & & Human error & $\begin{array}{l}\text { Melakukan pembimbingan untuk tenaga kerja } \\
\text { baru dan pengontrolan bagi tenaga kerja lama }\end{array}$ \\
\hline \multirow[t]{3}{*}{2} & Risiko Harga/Pasar & Fluktuasi harga output & $\begin{array}{l}\text { Melakukan kerjasama berkontrak dengan } \\
\text { perusahaan pembeli }\end{array}$ \\
\hline & & & Menyimpan hasil pengeringan \\
\hline & & $\begin{array}{l}\text { Pemutusan kontrak } \\
\text { pembelian/penurunan } \\
\text { permintaan }\end{array}$ & $\begin{array}{l}\text { Membuat tujuan pasar lebih dari satu dengan } \\
\text { prioritas dan membuat kontrak berjangka waktu }\end{array}$ \\
\hline 3 & Risiko Finansial & Kekurangan modal kerja & Melakukan pinjaman modal kerja \\
\hline \multirow[t]{2}{*}{4} & Risiko Kelembagaan & Moral hazard & $\begin{array}{l}\text { Menetapkan sanksi yang tegas terhadap tindakan } \\
\text { moral hazard dengan berdasarkan pertimbangan } \\
\text { yang telah disepakati bersama }\end{array}$ \\
\hline & & Pelanggaran kontrak & $\begin{array}{l}\text { Membuat kontrak bermatrai yang dipegang oleh } \\
\text { masing-masing pihak dan jika telah terjadi } \\
\text { menyelesaikan dengan jalan musyawarah } \\
\text { terlebih dahulu }\end{array}$ \\
\hline
\end{tabular}

Lampiran 2. Biaya Investasi Awal

\begin{tabular}{|c|c|c|c|c|}
\hline \multirow{2}{*}{ Uraian } & \multirow{2}{*}{ Unit } & \multirow{2}{*}{ Jumlah } & \multicolumn{2}{|c|}{ Biaya (Rp 000) } \\
\hline & & & Satuan & Jumlah biaya \\
\hline Peralatan produksi & & & & 94352 \\
\hline Infrastruktur & & & & 5000 \\
\hline Biaya promosi & Tahun & 1 & 10000 & 10000 \\
\hline Biaya sertifikasi & kali & 1 & 30000 & 30000 \\
\hline Biaya beli tanah, bangunan, pendirian usaha & $\mathrm{m}^{2}$ & 150 & 1200 & 185000 \\
\hline Total & & & & 324352 \\
\hline
\end{tabular}


Lampiran 3. Biaya Penyusutan

\begin{tabular}{|c|c|c|c|c|c|c|}
\hline \multirow[b]{2}{*}{ Uraian } & \multirow[b]{2}{*}{ Unit } & \multirow[b]{2}{*}{ Satuan } & \multirow[b]{2}{*}{$\begin{array}{c}\text { Umur } \\
\text { Ekonomis }\end{array}$} & \multicolumn{2}{|c|}{ Biaya (Rp 000) } & \multirow[b]{2}{*}{$\begin{array}{c}\text { Biaya } \\
\text { penyusutan }\end{array}$} \\
\hline & & & & $\begin{array}{l}\text { Harga } \\
\text { satuan }\end{array}$ & $\begin{array}{c}\text { Jumlah } \\
\text { Biaya }\end{array}$ & \\
\hline \multicolumn{7}{|l|}{ Peralatan produksi } \\
\hline Mesin pemecah pala & 1 & Unit & 10 & 10000 & 10000 & 1000 \\
\hline Mesin pengering $40 \mathrm{rak}$ & 1 & Unit & 10 & 40000 & 40000 & 4000 \\
\hline Mesin pengering $20 \mathrm{rak}$ & 1 & Unit & 10 & 19000 & 19000 & 1900 \\
\hline Timbangan digital & 1 & Unit & 5 & 1350 & 1350 & 270 \\
\hline Timbangan mekanik & 2 & Unit & 10 & 2350 & 4700 & 470 \\
\hline Sarung tangan kain & 2 & pasang & 1 & 15 & 30 & 30 \\
\hline Sandal & 5 & pasang & 5 & 10 & 50 & 10 \\
\hline Ayakan & 2 & Unit & 5 & 100 & 200 & 40 \\
\hline Saringan kapur & 1 & Unit & 5 & 4.5 & 5 & 0.9 \\
\hline Tirisan & 3 & Unit & 5 & 23.8 & 71 & 14.3 \\
\hline Baskom besar & 10 & Unit & 5 & 20 & 200 & 40 \\
\hline Tampah besar & 100 & Unit & 1 & 15 & 1500 & 1500 \\
\hline Pisau & 5 & Unit & 1 & 4.5 & 23 & 22.5 \\
\hline Tempat sampah & 3 & Unit & 5 & 35 & 105 & 21 \\
\hline Ember besar & 2 & Unit & 5 & 75 & 150 & 30 \\
\hline Drum & 3 & Unit & 10 & 200 & 600 & 60 \\
\hline Saluran air & 1 & Set & 10 & 2000 & 2000 & 200 \\
\hline Tempat sampah besar & 3 & Unit & 5 & 35 & 105 & 21 \\
\hline Mesin Diesel 8.5 PK & 1 & unit & 10 & 13579 & 13579 & 135.9 \\
\hline Meja kantor & 5 & unit & 3 & 50 & 250 & 83.3 \\
\hline Drum hasil sisa & 1 & set & 10 & 500 & 500 & 50 \\
\hline Tong sampah & 2 & unit & 5 & 20 & 40 & 8 \\
\hline \multicolumn{7}{|l|}{ Infrastruktur } \\
\hline Bangunan pabrik & 150 & $\mathrm{~m}^{2}$ & 15 & 1200 & 180000 & 12000 \\
\hline Rak besi pengeringan & 1 & unit & 10 & 2000 & 2000 & 200 \\
\hline Pembuatan sumur & 1 & set & 15 & 3000 & 3000 & 200 \\
\hline Total & & & & & & 23507.9 \\
\hline
\end{tabular}

Lampiran 4. Biaya Tetap

\begin{tabular}{|c|c|c|c|c|c|c|}
\hline \multirow{2}{*}{ No } & \multirow{2}{*}{ Komponen biaya } & \multirow{2}{*}{ Satuan } & \multirow{2}{*}{ Jumlah } & \multicolumn{3}{|c|}{ Jumlah biaya (Rp 000) } \\
\hline & & & & Satuan & Per bulan & Per tahun \\
\hline 1 & Gaji tenaga kerja tetap & orang & 3 & & 7400 & 88800 \\
\hline 2 & Upah tenaga kerja produksi & orang & 4 & & 5600 & 67200 \\
\hline 3 & Pemasaran & & & & 3000 & 36000 \\
\hline 4 & Pemeliharaan dan perawatan & & & & 1650 & 19800 \\
\hline 5 & Kebersihan dan keamanan & & & & 1200 & 14400 \\
\hline 6 & Listrik & kwh & 192 & 1.1 & 211.2 & 2534.4 \\
\hline 7 & Jasa profesional & & & & 1000 & 12000 \\
\hline 8 & Upah supir & orang & 2 & 500 & 1000 & 12000 \\
\hline 9 & Transportasi & & & & 4000 & 12000 \\
\hline & Total & & & & 24511.2 & 258134.4 \\
\hline
\end{tabular}


Lampiran 5. Biaya Variabel

\begin{tabular}{rllrrrr}
\hline \multirow{2}{*}{ No } & \multirow{2}{*}{ Biaya variabel } & \multirow{2}{*}{ Satuan } & \multirow{2}{*}{ Jumlah } & \multicolumn{3}{c}{ Biaya (Rp 000) } \\
\cline { 5 - 7 } & & & Per satuan & Per bulan & Per tahun \\
\hline 1 & Biaya bahan baku & Kg & 4575 & 20 & 91500 & 1098000 \\
2 & Bahan bakar mesin & Tabung & 13.15 & 112 & 1472.8 & 17673.6 \\
3 & Pengemasan & Box & 70 & & 1680 & 20160 \\
4 & Kapur & Kg & 1 & 5 & 100 & 1200 \\
5 & Bahan bakar solar & liter & 100 & 6.5 & 650 & 7800 \\
6 & Biaya rupa-rupa & bulan & & & 200 & 2400 \\
\hline & Total & & & & $\mathbf{9 5 6 0 2 . 8}$ & $\mathbf{1 ~ 1 4 7 ~ 2 3 3 . 6}$ \\
\hline
\end{tabular}



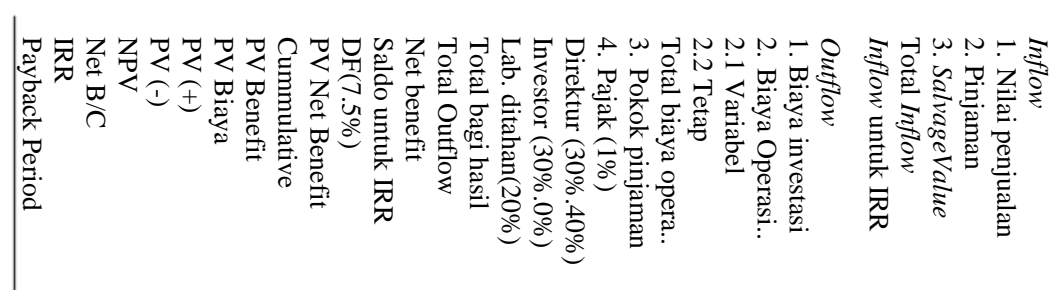

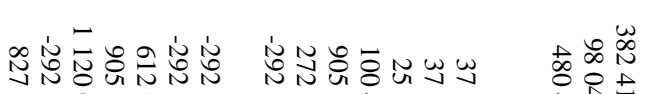

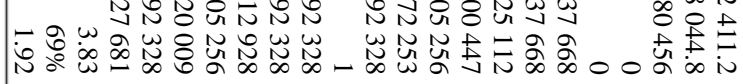

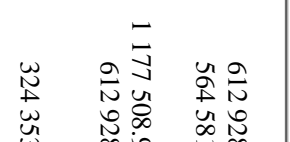

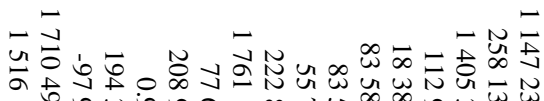

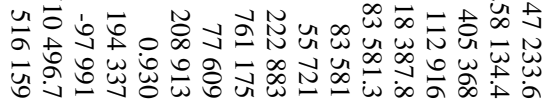

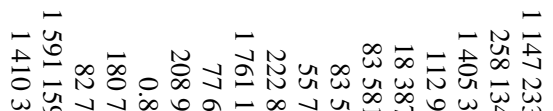

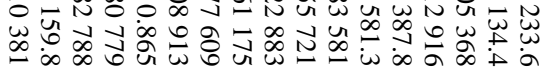

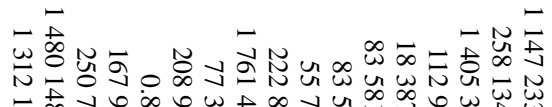

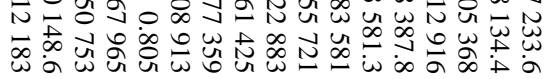

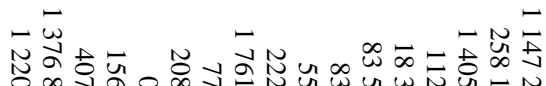

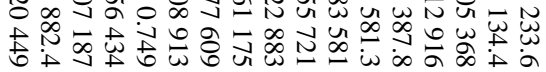

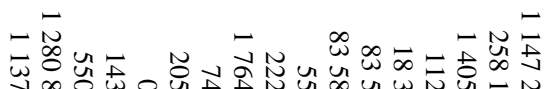

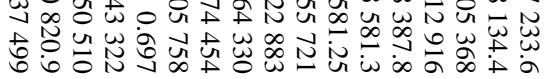

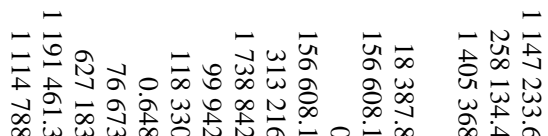

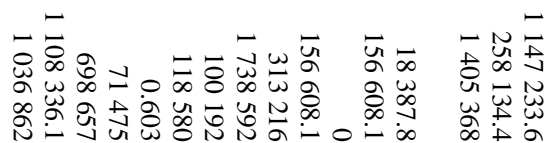

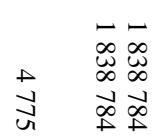

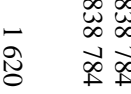

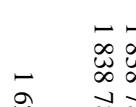

N

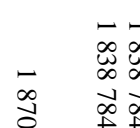

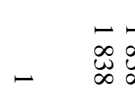

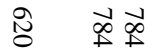

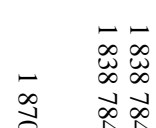

ठำ

$\stackrel{\substack{\infty \\ w}}{\infty}$

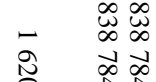

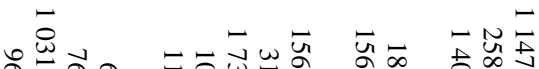

ஓं

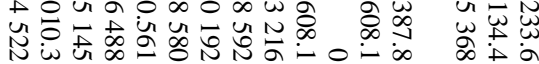

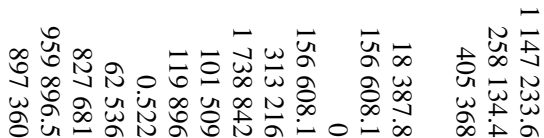
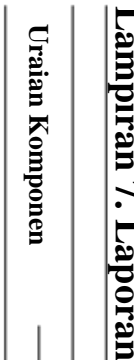

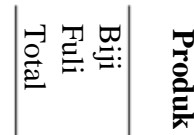

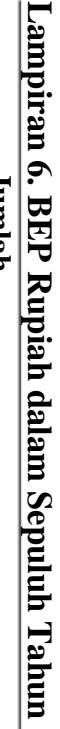

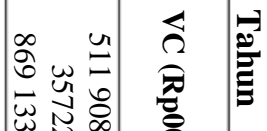

⿶凵

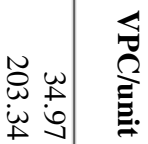

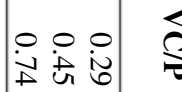

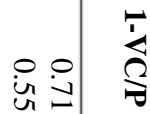

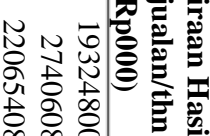

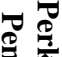

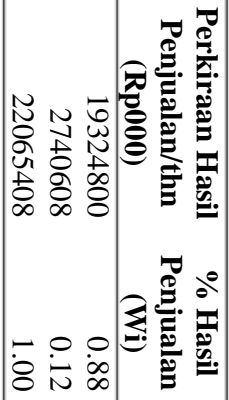

$\circ \div 0$

잉 웟

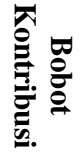

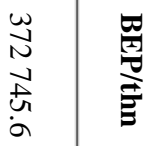




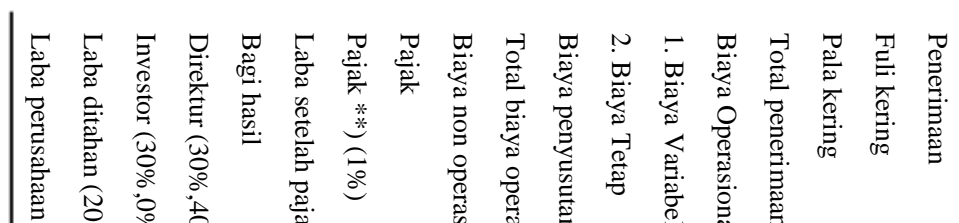

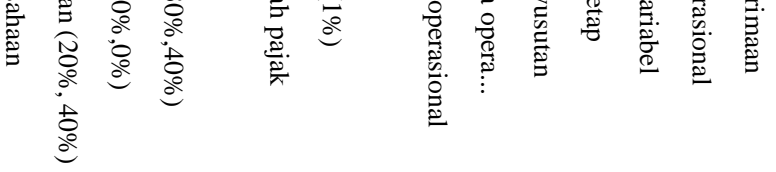

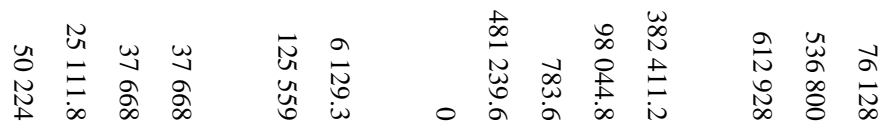

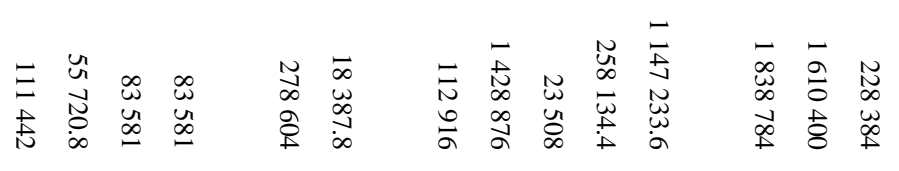

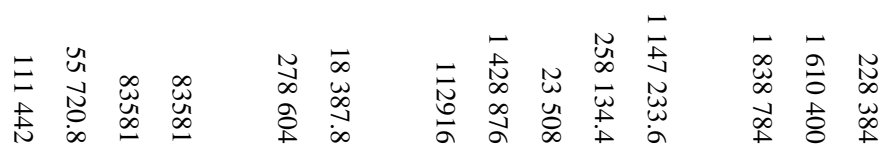

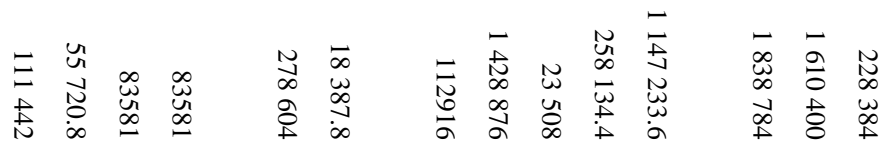

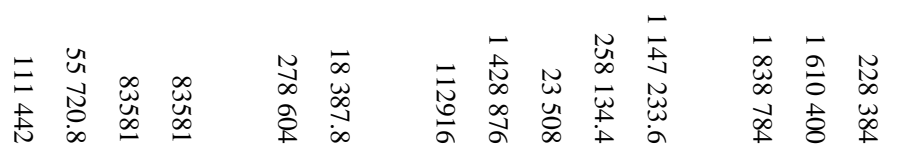

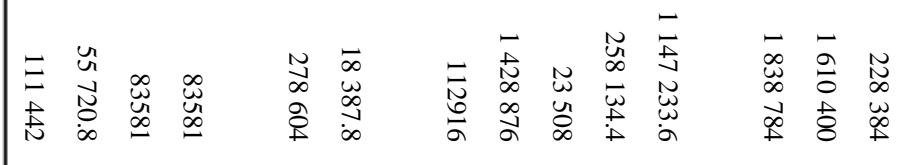

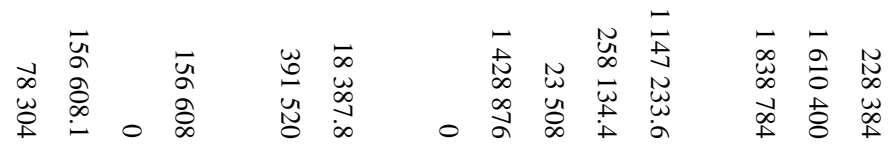

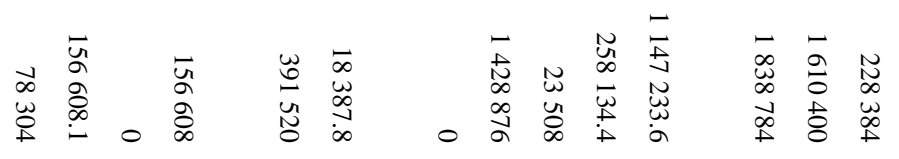

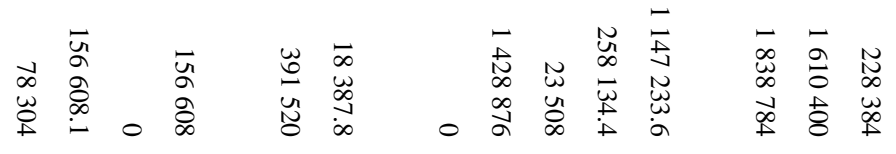

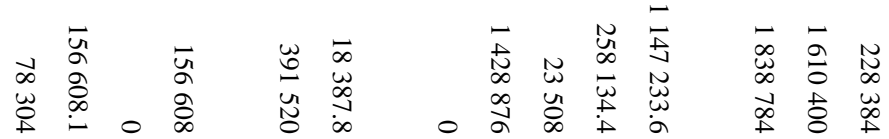

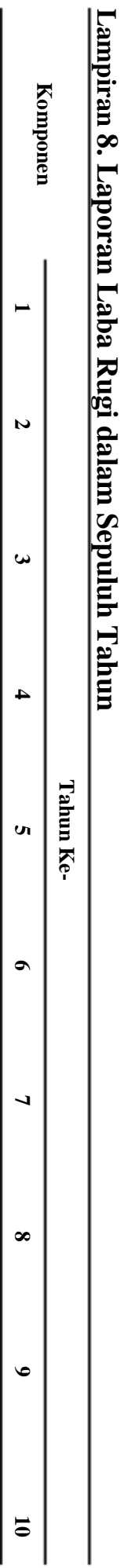


Monicha Septya Harni, dan Siti Jahroh 